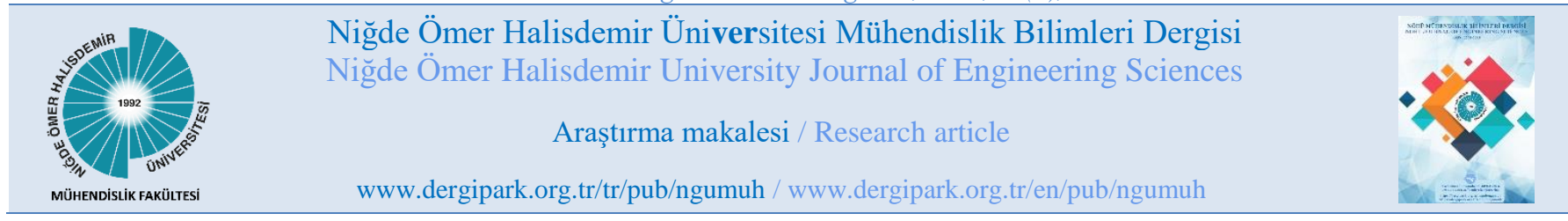

\title{
COVID-19 salgını dönemindeki kısıtlamaların sera gazı salınımına etkisi
}

\author{
Effect of the lockdown on greenhouse gas emissions during the COVID-19 \\ pandemic
}

\author{
Hülya Aykaç Özen ${ }^{1, *}$ \\ Ondokuz, Mayıs Üniversitesi, Çevre Mühendisliği Bölümü, 55139, Samsun Türkiye
}

\begin{abstract}
Özet
COVID-19 salgını nedeniyle, 2020 yılının Mart ayından itibaren alınan önlemler, dünya çapında çevreyi doğrudan veya dolaylı olarak etkileyen çıktıların görülmesine neden olmuştur. Bu bakış açısından yola çıkarak; Samsun'da, COVID-19 salgını döneminde ısınma amaçlı doğalgaz tüketiminden ve karayolu ulaşımından kaynaklı sera gazı emisyon değişimleri analiz edilmiştir. Sera gazları olan $\mathrm{CO}_{2}, \mathrm{CH}_{4}$ ve $\mathrm{N}_{2} \mathrm{O}$ emisyon miktarları COVID-19 salgını öncesi (Mart 2019 - Şubat 2020) ve COVID-19 salgını dönemini (Mart 2020 - Şubat 2021) kapsayacak şekilde, Hükümetler arası İklim Değişikliği Paneli (IPCC) tarafından kabul edilen bir metodoloji olan Tier yaklaşımı kullanılarak hesaplanmıştır. Yapılan değerlendirmeye göre, salgın döneminde ısınma ve karayolu ulaşımı sonucu açığa çıkan toplam sera gazı emisyon miktarı bir önceki yıla göre $17.3 \mathrm{Gg}$ azalmıştır. Bulgular, karbon ayak izi yükü açısından incelendiğinde, salgın döneminde doğalgaz kaynaklı tüketim sonucu $8.1552 \mathrm{Gg}$ eşdeğer $\mathrm{CO}_{2}$, karayolu ulaşımı kaynaklı ise $9.1412 \mathrm{Gg}$ eşdeğer $\mathrm{CO}_{2}$ emisyonunun atmosfere salınmadığını göstermektedir. Sonuç olarak, 2020 yılında COVID-19 salgınını kontrol altına almak için uygulanan önlemlerin, isınmada ve karayolu ulaşımında kullanılan yakıt tüketimini etkilediği ve toplam yakıt miktarının azalmasına katkı sağlayarak sera gazı emisyon miktarını düşürdüğü görülmüştür.
\end{abstract}

Anahtar kelimeler: COVID-19, Sera gazı, Karayolu ulaşımı, Doğalgaz, Karbon ayak izi

\section{Giriş}

2019 yılının sonlarında tanımlanan ve Dünya Sağlık Örgütü tarafindan salgın olarak ilan edilen korona virüs hastalığı (COVID-19), yirmi birinci yüzyılın en ciddi küresel sağlık durumlarından birini temsil etmektedir [1]. 31 Aralık 2019'da Çin'in Wuhan şehrindeki ilk vaka raporundan bu yana, COVID-19 hastalığı kısa sürede dünya çapında yayılmış ve halen etkisini devam ettirmektedir [2]. Semptomları; nezle ve gribe benzer olmakla birlikte, hastanın yaşı ve bağışıklı sistemine bağlı olarak daha şiddetli solunum yolu enfeksiyonları, nörolojik hastalıklar, çoklu organ disfonksiyonu ve hatta ölümcül sonuçlar görülebilmektedir. Bugüne kadar, virüsün yayılmasını

\begin{abstract}
Due to the COVID-19 epidemic, the measures taken in since March 2020 have led to outcomes that directly or indirectly affect the environment worldwide. Based on this point of view, greenhouse gas emission changes due to natural gas consumption and road transportation during the COVID-19 pandemic were analyzed in Samsun province. Emissions of greenhouse gases for $\mathrm{CO}_{2}, \mathrm{CH}_{4}$ and $\mathrm{N}_{2} \mathrm{O}$ were calculated using the Tier approach, a methodology adopted by the Intergovernmental Panel on Climate Change (IPCC) before and during the COVID-19 pandemic. According to results, the total amount of greenhouse gas emissions released due to natural gas and road transportation during the pandemic decreased by $17.3 \mathrm{Gg}$ compared to the previous year. When the findings are examined in terms of carbon footprint, $8.1552 \mathrm{Gg}$ equivalent $\mathrm{CO}_{2}$ emissions from natural gas consumption and $9.1412 \mathrm{Gg}$ equivalent $\mathrm{CO}_{2}$ emissions from road transportation were not released into the atmosphere during the pandemic period. In conclusion, the restrictions on mobility due to the COVID-19 epidemic have reduced the amount of greenhouse gas emissions by causing a decrease in the total amount of fuel resulting from heating and road transport.
\end{abstract}

Keywords: COVID-19, Greenhouse gas, Highway transport, Natural gas, Carbon footprint

tamamen önlemek için etkili bir tedavi yöntemi bulunamamıştır. 9 Eylül 2021 itibariyle, 223 ülkede 223441854 vaka bildirmiş ve 4610408 kişinin COVID-19 salgını nedeniyle hayatını kaybettiği kaydedilmiştir [3]. Türkiye de dahil olmak üzere çoğu ülke, salgının etkilerini azaltmak ve yeni korona virüsün bulaşmasını durdurmak için yasal kısitlama, sosyal kural ve önlemleri uygulamaya koymuştur [4-6]. Ülke çapında sokağa çıkma yasağ kapsamında restoranlar, sinemalar, okullar, alışveriş kompleksleri, eğitim kurumları gibi tüm sosyal toplanma yerleri kapatılmış, kronik hastalığı olanlar, hamileler ile 60 yaş üstü vatandaşların evlerinden çıkmaları yasaklanmış, kamu ve özel sektör çalışanları için esnek çalışma saatleri

\footnotetext{
* Sorumlu yazar/ Corresponding author, e-posta / e-mail: hulya.aykac@omu.edu.tr

Geliş / Recieved: 06.10.2021 Kabul / Accepted: 17.12.2021 Yayımlanma / Published: 14.01.2022

doi: 10.28948/ngmuh.1005439
} 
belirlenmiş, demiryolu, karayolu ve havayolu dahil olmak üzere her türlü ulaşım hizmetleri, temel hizmetler dışında askıya alınmıştır. Karantinanın uygulanmasıyla COVID19'un yayılmasını yavaşlatmayı amaçlayan hükümet politikaları, dünyadaki çoğu insan için çalışma ve yaşam alışkanlıklarını önemli ölçüde değiştirmiştir [7]. Davranıştaki bu ani değişiklik, konut ve ticari olarak kullanılan binaların doğalgaz talebini de etkilemiştir. Örneğin, COVID-19 önlemleri sonucu İtalya, Fransa ve İspanya'da sanayi sektörü tarafindan doğal gaz tüketimi sırasıyla $\% 25$, $\% 16$ ve $\% 14$ azalmıştır. Ayrıca, karantina döneminde doğalgaz dağıtımı İtalya, Belçika, Hollanda ve Polonya'nın her birinde ortalama \%15 oranında net bir düşüşe neden olmuştur [8]. Bir başka çalışmada, Mart 2020 döneminde konut sektöründe doğalgaz tüketimi 2019 ve 2018 yıllarının aynı dönemleri ile karşılaştırıldığında, birinci durumda $\% 12.79$ daha yüksek, ikinci durumda $\% 27.08$ daha düşük olduğu sonucuna varılmıştır [9]. COVID-19 salgınında uygulanan kısitlamaların bir diğer etkisi de karayolu ulaşımında görülmüştür. Sokağa çıkma kısıtlaması uygulanan süre ve günlerde zorunlu haller dişında vatandaşların toplu ulaşım vasıtaları dışında şehirlerarası seyahatlerine izin verilmemiş ve şehirlerarası ulaşımda şehirlerin giriş ve çıkışlarında kontrol noktaları oluşturulmuştur. $\mathrm{Bu}$ önlemler sonucu; araç sayısı azalarak trafik sıkışıklığı önlenmiş ve böylece mevcut araçların emisyon miktarında olumlu yönde düşüş görülmüştür. Cüce ve Uğur [10], COVID-19 tedbirleri sonucu Nevşehir genelinde azalan insan hareketliliği nedeniyle özellikle eşdeğer $\mathrm{CO}_{2}$ emisyonunun 2020 y1lı Mart-Ekim döneminde geçmiş yılların Mart-Ekim dönemi ortalamasından düşük olduğunu raporlamışlardır. Benzer bir çalışma Çin'in Pekin şehrinde gerçekleştirilmiş, COVID-19'un etkisi nedeniyle uygulanan karantina sırasında ortalama günlük trafik hacminin 2020 'de $\% 38.2$ oranında azaldı $\breve{g} 1$ ve birincil atmosferik kirleticilerin günlük emisyonları, 2020'de 2019 'un aynı dönemine göre \%29.2 azalma gösterdiği belirtilmiştir [11]. Kolombiya'da COVID-19 karantina döneminde ulaşımdan kaynaklanan emisyonlardaki değişiklikleri analiz etmek için, IPCC Kılavuz İlkeleri ile uyumlu standart bir metodoloji kullanılmış ve $\mathrm{CH}_{4}, \mathrm{~N}_{2} \mathrm{O}$ ve $\mathrm{CO}_{2}$ sera gazı emisyonlarında sirasıly $\% 17, \% 21$ ve $\% 28$; $\mathrm{CO}$ ve NMVOC gazlarında sirasiyla $\% 21$ ve $\% 22$, NOx miktarında ise $\% 15$ 'e kadar azalma olduğunu ifade edilmiştir [12]. COVID-19 salgını sirasında literatürde de bahsedildiği gibi, 1sınma kaynaklı doğal gaz tüketimi ve karayolu ulaşımındaki değişiklikler, küresel isınmayla mücadele noktasında hava kalitesi üzerinde olumlu katkı oluşturmuştur. $\mathrm{Bu}$ noktada, karbon ayak izi ile oluşan potansiyel etkilerin nedenlerini ve etkilerini anlamak mümkün olabilmektedir. Karbon ayak izi, faaliyetlerin fosil yakıtların yakılması yoluyla üretilen karbondioksit miktarı üzerindeki etkisinin bir ölçüsü olarak ifade edilmektedir [13]. İklim değişikliği ile ilgili bilimsel değerlendirmeler yapan IPCC, sera gazı emisyonlarını daha iyi yönetmek ve emisyon azaltma önlemlerini belirlemek için kuruluşların emisyonlarının nerede oluştuğunu daha iyi anlamasının yolunun karbon ayak izi hesaplanmasının olduğunu ifade etmiş̧tir [14].
$\mathrm{Bu}$ çalışma, COVID-19 salgını döneminde uygulanan kısıtlamaların Samsun'da iklim değişikliği açısından yarattığı etkiyi incelemeyi amaçlamaktadır. Bu kapsamda, IPCC tarafindan kabul edilen bir metodoloji olan Tier yaklaşımı kullanılarak, COVID-19 salgını öncesi ve sırasında Samsun'da 1sınma amaçlı doğalgaz kullanımından ve karayolu ulaşımından kaynaklanan karbon ayak izi çalışması gerçekleştirilmiş̧ir.

\section{Materyal ve metot}

\subsection{Veri temini}

Samsun'da, COVID-19 salgını döneminde uygulanan kısıtlamaların; 1sınma amaçlı doğalgaz kullanımına ve ulaşımdan kaynaklanan yakıt tüketimine ve dolayısıyla sera gazı salınımına etkisini değerlendirmek için, çalışma periyodu salgın öncesi (Mart 2019 - Şubat 2020) ve salgın dönemi (Mart 2020 - Şubat 2021) olarak ikiye ayrılmıştır. Doğalgazdan kaynaklı karbon ayak izi miktarını hesaplayabilmek için Samsun Doğal Gaz Dağıtım A.Ş. (SAMGAZ) kurumundan; Mart 2019 ile Şubat 2021 tarihleri arasinda mevcut aktif abone sayısı ve aktif abonelere ait doğalgaz tüketim miktarları temin edilmiştir (Şekil 1). SAMGAZ, Enerji Piyasası Düzenleme Kurumunun 06.07.2004 tarih ve DAG/336-12/058 sayll kurul kararı ile Tekkeköy, Canik, İlkadım, Atakum ve Kavak ilçelerinde kesintisiz olarak hizmet vermektedir. Dolayısıyla, Samsun'un 5 ilçesindeki veriler kullanılarak çalışma gerçekleştirilmiştir. Samsun'da salgın döneminde uygulanan kısıtlamaların karayolundan kaynaklanan karbon ayak izi miktarına etkisini hesaplayabilmek için ise, Mart 2019 Şubat 2020 ve Mart 2020 - Şubat 2021 tarihlerinde, taşıtlarda kullanılan yakıt türleri ve yakıtların miktarları, T.C. Enerji Piyasası Düzenleme Kurumu (EPDK) Petrol Piyasası Sektör Raporu ile Sıvılaştırılmış Petrol Gazları (LPG) Piyasası Sektör Raporu'ndan temin edilmiştir [15-20]. Buna göre Samsun'da benzin, motorin ve LPG olmak üzere üç farklı yakıt türleri ve bu yakıtların tüketim miktarları çalışmada değerlendirmeye alınan dönemi kapsayacak şekilde aylık olarak Tablo 4'te verilmiştir. Bu bilgiler ışığında Samsun'da salgın öncesinde ve salgın döneminde uygulanan kısıtlamalar sonucu hem doğalgaz hem de ulaşımdan kaynaklanan yakıt tüketimine bağlı karbon ayak izi değişimi hesaplanmıştır

\subsection{Karbon ayak izi hesaplama yöntemi}

Karbon ayak izinin belirlenmesi, IPCC tarafindan geliştirilen yöntem olan Tier-1, Tier-2 ve Tier-3 olmak üzere üç farklı yaklaşım ile yapılmaktadır. Bu çalışmada, uygulanması basit ve hızlı olan ayrıca yakıt miktarı ile oluşacak emisyonun yakıtla orantılı olarak ortaya çıkması prensibine dayanan Tier-1 yöntemi seçilmiştir. Hesaplamalar COVID-19 salgını öncesi (Mart 2019 - Şubat 2020) ve COVID-19 salgını dönemini (Mart 2020 - Şubat 2021) kapsayacak şekilde gerçekleştirilmiştir. Isınma amaçlı doğalgaz kullanımından kaynaklı karbon ayak izinin belirlenmesi için gerekli olan emisyon faktörleri IPCC'nin 2006 yılında yayınlamış olduğu raporda yer almakta olup, Tablo 1'de verilmiştir. 
Tablo 1. Kaynağa göre emisyon faktörleri [14].

\begin{tabular}{cll}
\hline $\begin{array}{c}\text { Sera Gazı Emisyon } \\
\text { kaynağı }\end{array}$ & \multicolumn{1}{c}{ Emisyon faktörü } & \multicolumn{1}{c}{ Birimi } \\
\hline Doğalgaz & 1.88496 & $\mathrm{~kg} / \mathrm{m}^{3} \mathrm{CO}_{2}$ \\
Doğalgaz & 0.000168 & $\mathrm{~kg} / \mathrm{m}^{3} \mathrm{CH}_{4}$ \\
Doğalgaz & 0.00000336 & $\mathrm{~kg} / \mathrm{m}^{3} \mathrm{~N}_{2} \mathrm{O}$ \\
\hline
\end{tabular}

Samsun'da doğalgaz kullanımı kaynaklı karbon ayak izinin tahminlenmesi sirasında, emisyonlarının $\mathrm{CO}_{2}$ cinsinden eşdeğerleri kullanarak hesaplanması amaçlanmaktadır. Bu amaçla, salgın öncesi ve salgın döneminde Samsun'da doğalgaz tüketim miktarları temin edilmiş (Şekil 1) ve Tablo 1'de yer alan emisyon faktörleri ile çarpılarak $\mathrm{CO}_{2}, \mathrm{CH}_{4}$ ve $\mathrm{N}_{2} \mathrm{O}$ emisyon miktarları Denklem (1) kullanılarak hesaplanmıştır (IPCC 1996):

Emisyon $(\mathrm{Gg})=$ Toplam Tüketim Miktarı $\left(\mathrm{m}^{3}\right)^{*}$ Emisyon Faktörü $\left(\mathrm{kg} / \mathrm{m}^{3}\right) * 10^{-6}$

Emisyon miktarları elde edildikten sonra $\mathrm{CO}_{2}, \mathrm{CH}_{4}$ ve $\mathrm{N}_{2} \mathrm{O}$ emisyonları için IPCC, AR-5:5 Değerlendirme Raporunda tanımlanan Küresel Isınma Potansiyeli (GWP) değerleri kullanılarak eşdeğer $\mathrm{CO}_{2}$ miktarları hesaplanmıştır (Tablo 2). Örnek olarak; salgın öncesi dönemde isınmadan kaynaklanan doğalgaz tüketimi sonucu oluşan $\mathrm{CO}_{2}$ ve $\mathrm{CH}_{4}$ emisyonları ile bu emisyonların eşdeğer $\mathrm{CO}_{2}$ miktarları aşağıdaki gibi hesaplanmıştır.

\section{$\mathrm{CO}_{2}$ emisyonu hesabl}

Doğalgaz tüketim miktarı $=249449253 \mathrm{~m}^{3}$

Emisyon Faktörü $=1.88496 \mathrm{~kg} / \mathrm{m}^{3}$

$\mathrm{CO}_{2}$ emisyonu $(\mathrm{Gg})=$ Doğalgaz tüketim miktar1*Emisyon Faktörü

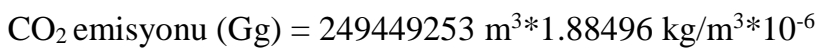
$=470.209 \mathrm{Gg}$

Eşdeğer $\mathrm{CO}_{2}=\mathrm{CO}_{2}$ Emisyon miktarı*GWP $=470.209 \mathrm{Gg} * 1=470.209 \mathrm{Gg}$

\section{$\mathrm{CH}_{4}$ emisyonu hesabl}

Doğalgaz tüketim miktarı $=249449253 \mathrm{~m}^{3}$

Emisyon Faktörü $=0.000168 \mathrm{~kg} / \mathrm{m}^{3}$

$\mathrm{CH}_{4}$ emisyonu $(\mathrm{Gg})=$ Doğalgaz tüketim miktar1*Emisyon Faktörü

$\mathrm{CH}_{4}$ emisyonu $(\mathrm{Gg})=249449253 \mathrm{~m}^{3 *} 0.000168 \mathrm{~kg} / \mathrm{m}^{3 *} * 10^{6}$ $=0.0419 \mathrm{Gg}$

Eşdeğer $\mathrm{CO}_{2}\left(\mathrm{CH}_{4}\right)=\mathrm{CH}_{4}$ Emisyon miktar1*GWP $=0.0419 \mathrm{Gg} * 28=1.1734 \mathrm{Gg}$

Yukarıdaki hesaplamalara göre, Samsun ilinde 1sınma amaçlı doğalgaz kullanımından kaynaklanan sera gazlarının salgın öncesi ve dönemindeki miktarları ve karbon ayak izlerinin belirlenmesi ayrıntılı olarak Tablo 3'te verilmişstir. Karayolu ulaşımında kullanılan yakıt çeşitlerine göre tüketim değerleri (ton) her bir yakıt türü için belirlendikten sonra (Tablo 4), IPCC Kılavuzu'ndan alınan dönüşüm faktörleri uygulanmıştır (Tablo 2). Bu sayede tüketilen yakıt miktarına karşılık gelen enerji içeriğine veya enerji tüketimi birimine (TJ) geçilmiştir. Bir sonraki adımda Tablo 2'de verilmiş olan emisyon faktörleri kullanılarak, tüketilen yakıtın emisyon içeriği bulunmuştur. Burada yakıt türüne göre emisyon faktörleri kullanılarak emisyon içeriği $\mathrm{Gg}$ cinsinden elde edilmiştir. Çalışma kapsamında değerlendirmeye alınan gazlar olan $\mathrm{CO}_{2}, \mathrm{CH}_{4}$ ve $\mathrm{N}_{2} \mathrm{O}$ emisyonları için IPCC, AR-5:5. Değerlendirme Raporunda tanımlanan Küresel Isınma Potansiyeli değerleri kullanılmıştır (Tablo 2).

Tablo 2. Farklı yakıt türlerinde kullanılacak emisyon faktörleri ve katsayılar [21]

\begin{tabular}{cccccccc}
\hline $\begin{array}{c}\text { Yakıt } \\
\text { Tipi }\end{array}$ & $\begin{array}{c}\text { Dönüşüm } \\
\text { Faktörü } \\
\text { (TJ/Gg) }\end{array}$ & $\begin{array}{c}\text { Emisyon } \\
\text { Faktörleri } \\
\text { (kg/TJ) }\end{array}$ & \multicolumn{2}{c}{$\begin{array}{c}\text { Küresel Isınma } \\
\text { Katsayısı } \\
\text { (kg CO_eşd/kg) }\end{array}$} \\
\hline Benzin & 44.3 & 69300 & 33 & 3.2 & 1 & 28 & 265 \\
Motorin & 43.0 & 74100 & 3.9 & 3.9 & 1 & 28 & 265 \\
LPG & 47.3 & 63100 & 62 & 0.2 & 1 & 28 & 265 \\
\hline
\end{tabular}

Karayolu ulaşımından kaynaklanan emisyonlar Denklem (2) ve Denklem (3) kullanılarak hesaplanmıştır [22].

Enerji Tüketimi $(\mathrm{TJ})=$ Yakıt tüketimi $(\mathrm{Gg})^{*}$ Dönüşüm faktörü (TJ/Gg)

Emisyon $(\mathrm{Gg})=$ Enerji tüketimi $(\mathrm{TJ}) *$

Emisyon faktörü $(\mathrm{kg} / \mathrm{TJ}) * 10^{-6}$

Örnek olarak; salgın öncesi dönemde karayolu ulaşımından kaynaklanan benzin tüketimi sonucu oluşan $\mathrm{CO}_{2}$ ve $\mathrm{CH}_{4}$ emisyonları ile bu emisyonların eşdeğer $\mathrm{CO}_{2}$ miktarları aşağıdaki gibi hesaplanmıştır.

\section{$\mathrm{CO}_{2}$ emisyonu hesabı}

Benzin tüketim miktarı $=30704.6690$ ton

Dönüşüm faktörü $=44.3 \mathrm{TJ} / \mathrm{Gg}$

Enerji Tüketimi $(\mathrm{TJ})=30704.6690$ ton $* 44.3 \mathrm{TJ} / \mathrm{Gg} * 10^{-3}$

$$
=1360.2168 \mathrm{TJ}
$$

Emisyon faktörü $=69300 \mathrm{~kg} / \mathrm{TJ}$

$\mathrm{CO}_{2}$ emisyonu $(\mathrm{Gg})=1360.2168 \mathrm{TJ} * 69300 \mathrm{~kg} / \mathrm{TJ} * 10^{-6}$

$$
=94.2630 \mathrm{Gg}
$$

Eşdeğer $\mathrm{CO}_{2}=\mathrm{CO}_{2}$ Emisyon miktarı*GWP $=94.2630 \mathrm{Gg} * 1=94.2630 \mathrm{Gg}$

$\mathrm{CH}_{4}$ emisyonu hesabl

Benzin tüketim miktarı $=30704.6690$ ton

Dönüşüm faktörü $=44.3 \mathrm{TJ} / \mathrm{Gg}$

Enerji Tüketimi (TJ) = 30704.6690 ton*44.3 TJ/Gg*10 $0^{-3}$ $=1360.2168 \mathrm{TJ}$

Emisyon faktörü $=33 \mathrm{~kg} / \mathrm{TJ}$

$\mathrm{CH}_{4}$ emisyonu $(\mathrm{Gg})=1360.2168 \mathrm{TJ} * 33 \mathrm{~kg} / \mathrm{TJ} * 10^{-6}$ $=0.0449 \mathrm{Gg}$

Eşdeğer $\mathrm{CO}_{2}\left(\mathrm{CH}_{4}\right)=\mathrm{CH}_{4}$ Emisyon miktarı*GWP $=0.0449 \mathrm{Gg} * 28=1.2568 \mathrm{Gg}$ 
Samsun ilinde karayolları ulaşımından kaynaklanan sera gazlarının salgın öncesi ve salgın dönemindeki değerleri Tablo 5'te ayrıntılı olarak yer almaktadır. $\mathrm{Bu}$ yaklaşımla; emisyon hesaplaması için tüketilen yakıt miktarı ve standart emisyon faktörlerinin belirlenmesi olmak üzere iki ana nokta yeterlidir. Çalışma kapsamında değerlendirmeye alınan dönem aralığında hem ısınma amaçlı doğalgaz kullanımı hem de ulaşım kaynaklı $\mathrm{CO}_{2}, \mathrm{CH}_{4}$ ve $\mathrm{N}_{2} \mathrm{O}$ emisyonları hesaplanarak sera gazı emisyon miktarı belirlenmiş ve karbon ayak izi bazında karakterize edilmiştir.

\section{3 Ístatistiksel analiz}

Isınma amaçlı doğalgaz tüketiminden ve karayolları ulaşımından kaynaklanan karbon ayak izi miktarlarını karşılaştırmak için, salgın öncesi ve salgın döneminde elde edilen veriler istatistiksel olarak değerlendirilmiştir. Değişkenlerin normal dağılıma uygunluğu Shapiro-Wilk testi ile incelenmiş ve değerlerin normal bir dağılım göstermesinden dolayı Paired-T testi uygulanmıştır. Verilerin analizinde $\% 5$ anlamlılık düzeyi kullanılarak SPSS (23. Sürüm) paket programı kullanılmıştır.

\section{Bulgular ve tartışma}

\subsection{Isınma amaçlı doğalgaz tüketiminden kaynaklanan karbon ayak izi miktarının hesabı}

Salgın döneminde, 1sınma amaçlı doğalgaz tüketiminin karbon ayak izine olan etkisini incelemek amaciyla SAMGAZ Doğal Gaz Dağıtım A.Ş. kurumundan Mart 2019 ile Şubat 2021 tarihleri arasında mevcut aktif abone sayısı ve aktif abonelere ait doğalgaz tüketim miktarları alınarak, çalışma; salgın öncesi (Mart 2019 - Şubat 2020) ve salgın dönemi (Mart 2020 - Şubat 2021) olarak iki başlık altında irdelenmiştir. Dönemsel olarak toplam abonelik sayısı ve toplam doğalgaz tüketim miktarları Şekil 1'de gösterilmiştir. Ayrıca, aylara göre abone başına düşen doğalgaz tüketim miktarları hesaplanarak elde edilen sonuçlar, Şekil 2'de sunulmuştur. Samsun'da çalışma kapsamında değerlendirmeye alınan salgın öncesi döneminde toplam doğalgaz abone sayısı 202181, salgın döneminde ise 216578 kişidir. Buna karşılık doğalgaz toplam tüketim miktarları incelendiğinde; salgın öncesinde $249449253 \mathrm{~m}^{3}$, salgın döneminde ise $245135594 \mathrm{~m}^{3}$ tüketim gerçekleşmiştir. Yani, salgın döneminde abone sayısı artmasına rağmen doğalgaz tüketiminde azalma söz konusudur. Salgın döneminde uygulanan kısıtlamaların insanların yaşam alışkanlıklarını değiştirerek binalardaki doğalgaz ihtiyacını etkilediğini göstermektedir. Abone başına düşen doğalgaz tüketim miktarları salgın öncesi ve salgın dönemi olarak karşılaştırılmış ve aşağıdaki sonuçlar elde edilmiştir: Mart 2020'de salgının başlamasıyla abone başına düşen tüketim miktarı Mart 2019 yılına göre sadece \%1.79 azalma göstermiştir.

Mart ayının ortasında Türkiye'de ilk vakanın görülmesi ve ayın sonunda sadece 65 yaş üstü vatandaşların sokağa çıkmasının yasaklanması, Mart ayında doğalgaz tüketiminde etkili bir değişime sebep olmamıştır. Nisan ayından itibaren tüm okul ve üniversitelerin yüz yüze eğitim yerine uzaktan eğitim sistemi uygulaması, çalışanlar için esnek çalışma saatlerinin belirlenmesi, iki hafta kısmi kapanma olması ve hafta sonları sokağa çıkma yasağı ilan edilmesi, kişilerin evde kalma süresinin artmasına ve özellikle Mayıs 2020 döneminde doğalgaz tüketiminde artışa neden olduğu tahmin edilmektedir. 2020 yılının Mayıs ayında, önceki yılın aynı dönemine göre abone başı tüketim miktarlarında \%4.53 artış söz konusudur.

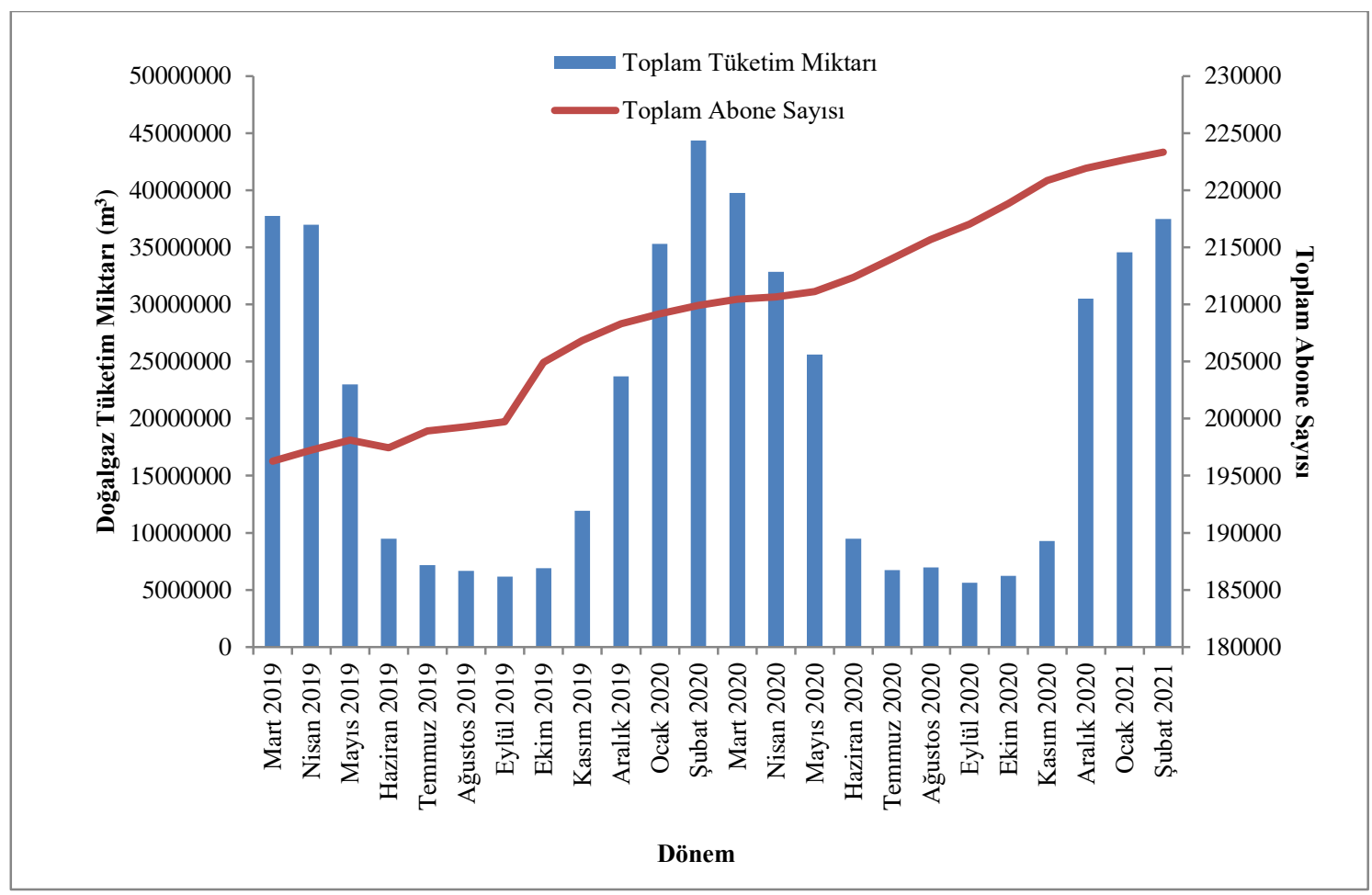

Şekil 1. Mart 2019-Şubat 2021 döneminde Samsun'da 1sınma amaçlı tüketilen doğalgaz miktarları 


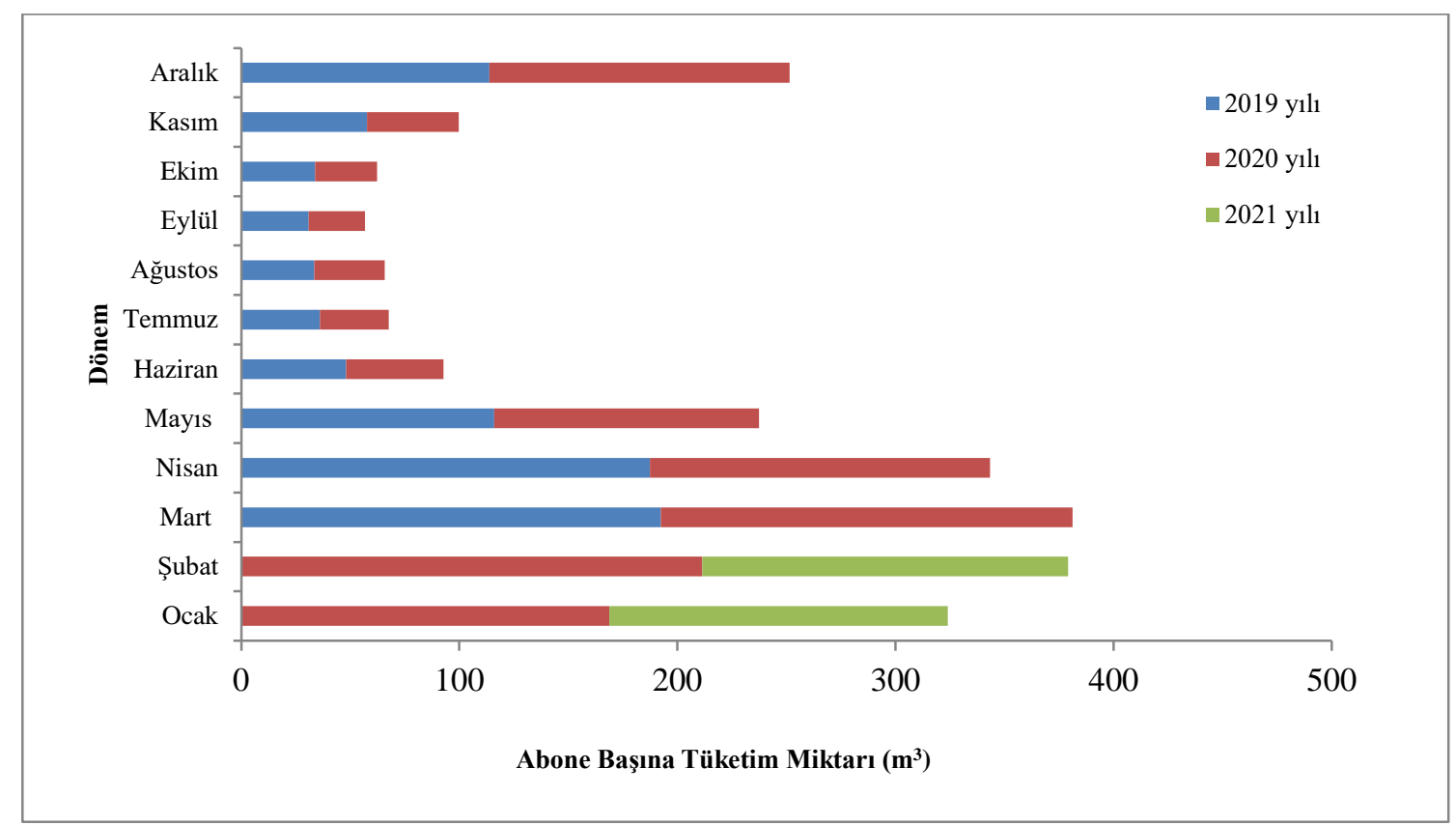

Şekil 2. Mart 2019 - Şubat 2021 döneminde aylara göre abone başına düşen doğalgaz tüketim miktarları

Salgın döneminde, Haziran ayından Aralık ayına kadar doğalgaz tüketimi azalma trendi sergilemiş ve Haziran, Temmuz, Ağustos, Eylül, Ekim, Kasım aylarında tüketimde sirasiyla \%7.04, \%12.71, \%3.44, \%16.04, \%15.61, \%27.06 oranında düşüş görülmüştür. Haziran ayından itibaren kontrollü normalleşme sürecine geçilmesi ve yaz döneminde kentten kırsal kesimlere göçün, salgın öncesi döneme göre doğalgaz tüketimini azalttığını düşündürmektedir. 2020 ve 2021 yılı Ocak ve Şubat ayları tüketim miktarları incelendiğinde Ocak ayında tüketim 2020 yılına göre $\% 8$, Şubat ayında ise \%20.64 düşüş sergilemiştir. 2021 yılında abone başı tüketim miktarının düşük olmasının sebebi insanların COVID-19 virüsünün olası etkilerinden korunmak için kalabalık ortamlardan uzaklaşıp yazlık ve kırsal bölgelere yerleşerek, buralarda 1sınma amaçlı diğer yakıtları kullanması ile doğalgaz kullanımının azalması olarak düşünülmektedir.

Samsun ilinde, doğalgaz abone sayıları ve toplam tüketim miktarları elde edildikten sonra, IPCC metodolojisine göre 1sınma amaçlı doğalgaz tüketiminden kaynaklanan karbon ayak izi miktarı belirlenmiştir. Doğalgaz tüketimi sonucu açığa çıkan $\mathrm{CO}_{2}, \mathrm{CH}_{4}$ ve $\mathrm{N}_{2} \mathrm{O}$ emisyonlarının miktarları hesaplanarak, her bir emisyon $\mathrm{CO}_{2}$ eşdeğeri üzerinden ifade edilmiştir. Salgın öncesi ve salgın döneminde oluşan emisyonlara ilişkin hesaplamalar Tablo 3'te verilmiştir. SAMGAZ'dan alınan veriler ve Tier-1 yaklaşımı ile yapılan hesaplamalar yardımı ile doğalgazdan kaynaklı sera gazı emisyon miktarları belirlenmiştir. Buna göre, salgın öncesi dönemde atmosfere salınan $\mathrm{CO}_{2}$ emisyonu $470.2019 \mathrm{Gg}, \mathrm{CH}_{4}$ emisyonu $0.0419 \mathrm{Gg}$ ve $\mathrm{N}_{2} \mathrm{O}$ emisyonu $0.0008 \mathrm{Gg}$ olarak hesaplanmıştır. Salgın döneminde ise $\mathrm{CO}_{2}, \mathrm{CH}_{4}$ ve $\mathrm{N}_{2} \mathrm{O}$ emisyon değerlerinin sirasiyla $462.0708 \mathrm{Gg}, 0.0412 \mathrm{Gg}$ ve $0.0008 \mathrm{Gg}$ olduğu sonucuna ulaşılmıştır. Çalışma kapsamında değerlendirmeye alınan salgın öncesi döneminde toplam sera gazı emisyon miktarı 470.2446 Gg iken, salgın döneminde $462.1128 \mathrm{Gg}$ değeri elde edilmiştir. Bulgular, Samsun'da salgın döneminde 1sınma amaçlı doğalgaz kaynaklı tüketimin $359471.75 \mathrm{~m}^{3}$ azalması ile yaklaşık $8.1318 \mathrm{Gg}$ sera gazı emisyonunun atmosfere salınmadığını göstermektedir.

Tablo 3.Samsun ilinde 1sınma amaçlı doğalgaz kullanımından kaynaklanan karbon ayak izi hesabı

\begin{tabular}{|c|c|c|c|c|c|c|}
\hline & $\begin{array}{c}\text { Doğalgaz Toplam } \\
\text { Tüketim Miktarı } \\
\qquad\left(\mathbf{m}^{\mathbf{3}}\right)\end{array}$ & $\begin{array}{c}\text { Emisyon } \\
\text { Faktörü̈ } \\
\left(\mathbf{k g} / \mathbf{m}^{3}\right)\end{array}$ & $\begin{array}{c}\text { Emisyon } \\
\text { Miktarl } \\
\text { (ton) }\end{array}$ & $\begin{array}{c}\text { Emisyon } \\
\text { Miktarı } \\
\text { (Gg) }\end{array}$ & $\begin{array}{l}\text { Küresel } \\
\text { Isinma } \\
\text { Potansiyeli }\end{array}$ & $\begin{array}{c}\text { Eşdeğer } \mathrm{CO}_{2} \\
\left(\mathrm{Gg} \mathrm{CO}_{2}\right)\end{array}$ \\
\hline \multicolumn{7}{|c|}{$\mathrm{CO}_{2}$ Emisyonu } \\
\hline Salgın öncesi & 249449253 & 1.88496 & 470201.8639 & 470.2019 & 1.00 & 470.2019 \\
\hline Salgın dönemi & 245135594 & 1.88496 & 462070.7893 & 462.0708 & 1.00 & 462.0708 \\
\hline \multicolumn{7}{|c|}{$\mathrm{CH}_{4}$ Emisyonu } \\
\hline Salgın öncesi & 249449253 & 0.000168 & 41.9075 & 0.0419 & 28.00 & 1.1734 \\
\hline Salgın dönemi & 245135594 & 0.000168 & 41.1828 & 0.0412 & 28.00 & 1.1531 \\
\hline \multicolumn{7}{|c|}{$\mathrm{N}_{2} \mathrm{O}$ Emisyonu } \\
\hline Salgın öncesi & 249449253 & 0.00000336 & 0.8381 & 0.0008 & 265.00 & 0.2221 \\
\hline Salgın dönemi & 245135594 & 0.00000336 & 0.8237 & 0.0008 & 265.00 & 0.2183 \\
\hline
\end{tabular}


Ayrıca, salgın öncesi ve salgın dönemi arasında doğalgaz kullanımından kaynaklanan $\mathrm{CO}_{2}, \mathrm{CH}_{4}$ ve $\mathrm{N}_{2} \mathrm{O}$ emisyonları için hesaplanan karbon ayak izi miktarları arasındaki ilişki istatistiksel olarak incelenmiştir. Buna göre, 1sınma amaçlı doğalgaz tüketimi sonucu oluşan karbon ayak izi miktarında salgın öncesi ve salgın dönemi arasında istatistiksel olarak anlamlı bir ilişki tanımlanamamıştır $(\mathrm{p}=0.72)$. Salgın öncesi dönemde oluşan toplam eşdeğer $\mathrm{CO}_{2}$ miktarı $471.5974 \mathrm{Gg}$, salgın döneminde eşdeğer $\mathrm{CO}_{2}$ miktarı $463.4422 \mathrm{Gg}$ olarak hesaplanmıştır. Salgın döneminde, doğalgaz kullanımının azalması ile toplam $8.1552 \mathrm{Gg}$ eşdeğer $\mathrm{CO}_{2}$ atmosfere verilmeyerek, $\mathrm{CO}_{2}$ salınımında $\% 1.73$ oranında düşüş gözlenmiştir. Elde edilen bu sonuçlar, 2020 yılında COVID19 salgını sebebiyle ülkemizde alınan tedbirlerin doğalgaz tüketimini etkilediği ve sosyal, ekonomik ve ticari faaliyetlerin değişimiyle ısınma amaçlı kullanılan doğalgaz kaynaklı emisyon miktarını az da olsa düşürdüğünü göstermektedir. Ancak, elde edilen sonuçlar birbirlerine yakın değerler olduklarından istatistiksel olarak anlamlı bir fark oluşturmamıştır.

\subsection{Karayolları ulaşımından kaynaklanan karbon ayak izi miktarının hesabı}

Samsun'da ulaşımda kullanılan yakıt türü ve miktarları, T.C. Enerji Piyasası Düzenleme Kurumu (EPDK) Petrol ve LPG Piyasası Sektör Raporları'ndan elde edilmiştir [15-20]. Mevcut verilerle; IPCC metodolojisi olan Tier-1 yaklaşımına göre, salgın öncesi ve salgın dönemini kapsayacak şekilde yakıt tüketimine bağlı karbon ayak izi değişimi hesaplanmıştır. Yakıt türleri ve dönemsel olarak yakıt tüketim miktarları Tablo 4'te gösterilmişstir. Samsun'da salgın öncesi dönemde karayolu ulaşımına ait benzin tüketim miktarı 30704.669 ton, motorin tüketim miktarı 456368.056 ton, LPG tüketim miktarı 61580.124 ton iken; salgın döneminde benzin, motorin ve LPG tüketim miktarları sırasıly 30731.259 ton, 460518.716 ton ve 54199.13 ton'dur. Toplam tüketilen yakıt miktarları çalışma kapsamında değerlendirmeye alınan her iki dönem için de incelendiğinde, salgın öncesi dönemde 548652.849 ton, salgın döneminde ise 545449.105 ton olarak hesaplanmıştır.

Salgın döneminde toplam karayolu ulaşımına ait yakıt miktarında 3203.744 ton azalma olduğunu görülmektedir. Azalmanın nedeni, COVID-19 virüsünün yayılmasını önlemek için uygulanan tedbirler olan uzaktan eğitim ve çalışma imkânlarının oluşması, sokağa çıkma yasağı ve şehirlerarası seyahat kısıtlamaları gibi doğrudan ulaşımı etkileyen yaptırımlar ile ilişkilendirilebilmektedir.

Samsun ilinde karayolu ulaşımında kullanılan yakıt türleri için tüketim değerleri belirlendikten sonra, tüketilen yakıt değerleri üzerinden IPCC k1lavuzunda yayınlanan Tier-1 yaklaşımı kullanılarak hesaplamalar yapılmıştır. Her yakıt türü için $\mathrm{CO}_{2}, \quad \mathrm{CH}_{4}, \quad \mathrm{~N}_{2} \mathrm{O}$ emisyon değerleri hesaplanarak elde edilen veriler, eşdeğer karbondioksit miktarı cinsinden ifade edilmiştir. Samsun ilinde salgın öncesi ve salgın döneminde karayolu araçlarında kullanılan yakıtlardan kaynaklanan emisyon miktarını gösteren hesaplamalar Tablo 5'te verilmiştir.
Tablo 4. Samsun ilinde belirlenen çalışma döneminde karayolu ulaşımına ait yakıt satış miktarları (ton)[15-20].

\begin{tabular}{|c|c|c|c|c|}
\hline \multicolumn{2}{|r|}{ Dönem } & \multicolumn{3}{|c|}{ Yakıt Türü } \\
\hline & & Benzin & Motorin & LPG \\
\hline \multirow{12}{*}{ 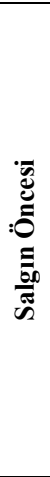 } & Mart 2019 & 2160.11 & 36490.23 & 4327.00 \\
\hline & Nisan 2019 & 2234.19 & 37194.13 & 4715.47 \\
\hline & Mayıs 2019 & 2430.76 & 39077.24 & 4763.43 \\
\hline & Haziran 2019 & 3105.05 & 35868.57 & 5834.30 \\
\hline & Temmuz 2019 & 3187.33 & 41339.32 & 5804.50 \\
\hline & Ağustos 2019 & 3822.34 & 41668.79 & 7041.32 \\
\hline & Eylül 2019 & 2429.93 & 38898.43 & 5506.21 \\
\hline & Ekim 2019 & 2464.01 & 40190.76 & 5060.02 \\
\hline & Kasim 2019 & 2423.66 & 41443.83 & 4855.93 \\
\hline & Aralık 2019 & 2275.24 & 35516.20 & 4721.59 \\
\hline & Ocak 2020 & 2122.18 & 33833.05 & 4775.90 \\
\hline & Şubat 2020 & 2049.86 & 34847.50 & 4174.47 \\
\hline \multirow{12}{*}{ 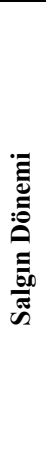 } & Mart 2020 & 2202.25 & 41707.35 & 3943.84 \\
\hline & Nisan 2020 & 1714.89 & 28474.42 & 3008.35 \\
\hline & Mayıs 2020 & 1926.11 & 31860.01 & 3207.45 \\
\hline & Haziran 2020 & 2937.21 & 41827.76 & 4965.80 \\
\hline & Temmuz 2020 & 3878.79 & 47879.99 & 6409.71 \\
\hline & Ağustos 2020 & 3943.54 & 46647.91 & 6741.97 \\
\hline & Eylül 2020 & 3147.33 & 47274.95 & 5298.64 \\
\hline & Ekim 2020 & 2514.50 & 41504.17 & 5239.73 \\
\hline & Kasim 2020 & 2617.29 & 40704.2 & 4590.22 \\
\hline & Aralık 2020 & 1916.01 & 36714.58 & 3582.76 \\
\hline & Ocak 2021 & 2028.72 & 28885.18 & 3711.26 \\
\hline & Şubat 2021 & 1904.62 & 27038.21 & 3499.41 \\
\hline
\end{tabular}

Salgın öncesi dönemde Tier-1 yöntemine göre hesaplanan yakıt türleri için, $\mathrm{CO}_{2}, \mathrm{CH}_{4}$ ve $\mathrm{N}_{2} \mathrm{O}$ emisyon değerleri sirasiyla $1732.1824 \mathrm{Gg}, \quad 0.302 \mathrm{Gg}$ ve $0.0815 \mathrm{Gg}$ bulunmuştur. Salgın döneminde benzin, motorin ve LPG kullanımı ile oluşan toplam emisyon miktarı ise $\mathrm{CO}_{2}, \mathrm{CH}_{4}$ ve $\mathrm{N}_{2} \mathrm{O}$ gazları için sırasıyla $1723.4598 \mathrm{Gg}, 0.281 \mathrm{Gg}$ ve 0.0821 Gg hesaplanmıştır. Çalışmada COVID-19 salgını ortaya çıkmadan önce seçilen dönem aralığında ulaşımdan kaynaklanan toplam sera gazı emisyon miktarı 1732.5659 $\mathrm{Gg}$ iken salgın döneminde 1723.8230 Gg değerine ulaşılmıştır. Sonuçlardan da anlaşılacağı üzere, salgın karantinası döneminde karayolu ulaşımında yakıt tüketiminin 3203.744 ton azalması yaklaşı 8743 ton sera gazı emisyonunun atmosfere salınmadığını göstermektedir. Ayrıca, Tablo 5'te salgın döneminde ve önceki yılın aynı dönem aralığında tüketilen yakıt türlerine ait eşdeğer $\mathrm{CO}_{2}$ emisyon miktarları da yer almaktadır. Çalışma kapsamında değerlendirmeye alınan dönem aralığında Tier-1 yöntemine göre hesaplanan yakıt türlerine ait toplam eşdeğer $\mathrm{CO}_{2}$ emisyon miktarı 3515.3144 Gg'dır. Bu değerin 1762.2278 Gg miktarını salgından önceki dönem oluştururken, salgın döneminde ise $1753.0866 \mathrm{Gg}$ eşdeğer $\mathrm{CO}_{2}$ emisyonu oluşmuştur. COVID-19 salgın döneminde sıkı önlemlerin başında gelen seyahat kısıtlaması ve sokağa çıkma yasağının olduğu günlerde zorunlu haller dışında şehir içi toplu taşıma araçlarının kullanılmaması gibi tedbirler Samsun'da karayolları ulaşımından kaynaklanan eşdeğer $\mathrm{CO}_{2}$ miktarına etkisi önceki yılın aynı dönemi ile karşılaştırıldığında, yakıt tüketiminde $9.1412 \mathrm{Gg}$ azalma göstermiştir. 
Tablo 5. Samsun ilinde karayolu ulaşımından kaynaklanan karbon ayak izi hesabı

\begin{tabular}{|c|c|c|c|c|c|c|c|c|c|c|}
\hline & $\begin{array}{l}\text { Yakit } \\
\text { Türü }\end{array}$ & $\begin{array}{l}\text { Yakıt Tüketim } \\
\text { Miktarı (ton) }\end{array}$ & $\begin{array}{c}\text { Yakıt } \\
\text { Tüketim } \\
\text { Miktarı (Gg) }\end{array}$ & $\begin{array}{c}\text { Dönüşüm } \\
\text { Faktörü } \\
\text { (TJ/Gg) }\end{array}$ & $\begin{array}{l}\text { Enerji } \\
\text { Tüketimi } \\
\text { (TJ) }\end{array}$ & $\begin{array}{c}\text { Emisyon } \\
\text { Faktörü } \\
(\mathbf{k g} / \mathrm{TJ})\end{array}$ & $\begin{array}{l}\text { Emisyon } \\
\text { İçeriği (kg) }\end{array}$ & $\begin{array}{l}\text { Emisyon } \\
\text { İçeriği } \\
\text { (Gg) }\end{array}$ & $\begin{array}{c}\text { Küresel } \\
\text { Isınma } \\
\text { Potansiyeli }\end{array}$ & $\underset{(\mathbf{G g})}{\text { Eşdeğer } \mathrm{CO}_{2}}$ \\
\hline \multicolumn{11}{|c|}{$\mathrm{CO}_{2}$ Emisyonu } \\
\hline \multirow[t]{3}{*}{ Salgın Öncesi } & Benzin & 30704.6690 & 30.7047 & 44.3 & 1360.2168 & 69300 & 94263026.8 & 94.2630 & 1 & 94.2630 \\
\hline & Motorin & 456368.0560 & 456.3681 & 43 & 19623.8264 & 74100 & 1454125536.8 & 1454.1255 & 1 & 1454.1255 \\
\hline & LPG & 61580.1240 & 61.5801 & 47.3 & 2912.7399 & 63100 & 183793885.5 & 183.7939 & 1 & 183.7939 \\
\hline \multirow[t]{3}{*}{ Salgın Dönemi } & Benzin & 30731.2590 & 30.7313 & 44.3 & 1361.3948 & 69300 & 94344657.8 & 94.3447 & 1 & 94.3447 \\
\hline & Motorin & 460518.7160 & 460.5187 & 43 & 19802.3048 & 74100 & 1467350784.8 & 1467.3508 & 1 & 1467.3508 \\
\hline & LPG & 54199.1290 & 54.1991 & 47.3 & 2563.6188 & 63100 & 161764346.4 & 161.7643 & 1 & 161.7643 \\
\hline \multicolumn{11}{|c|}{$\mathrm{CH}_{4}$ Emisyonu } \\
\hline \multirow[t]{3}{*}{ Salgın Öncesi } & Benzin & 30704.6690 & 30.7047 & 44.3 & 1360.2168 & 33 & 44887.2 & 0.0449 & 28 & 1.2568 \\
\hline & Motorin & 456368.0560 & 456.3681 & 43 & 19623.8264 & 3.9 & 76532.9 & 0.0765 & 28 & 2.1429 \\
\hline & LPG & 61580.1240 & 61.5801 & 47.3 & 2912.7399 & 62 & 180589.9 & 0.1806 & 28 & 5.0565 \\
\hline \multirow[t]{3}{*}{ Salgın Dönemi } & Benzin & 30731.2590 & 30.7313 & 44.3 & 1361.3948 & 33 & 44926.0 & 0.0449 & 28 & 1.2579 \\
\hline & Motorin & 460518.7160 & 460.5187 & 43 & 19802.3048 & 3.9 & 77229.0 & 0.0772 & 28 & 2.1624 \\
\hline & LPG & 54199.1290 & 54.1991 & 47.3 & 2563.6188 & 62 & 158944.4 & 0.1589 & 28 & 4.4504 \\
\hline \multicolumn{11}{|c|}{$\mathrm{N}_{2} \mathrm{O}$ Emisyonu } \\
\hline \multirow[t]{3}{*}{ Salgın Öncesi } & Benzin & 30704.6690 & 30.7047 & 44.3 & 1360.2168 & 3.2 & 4352.7 & 0.0044 & 265 & 1.1535 \\
\hline & Motorin & 456368.0560 & 456.3681 & 43 & 19623.8264 & 3.9 & 76532.9 & 0.0765 & 265 & 20.2812 \\
\hline & LPG & 61580.1240 & 61.5801 & 47.3 & 2912.7399 & 0.2 & 582.5 & 0.0006 & 265 & 0.1544 \\
\hline \multirow[t]{3}{*}{ Salgın Dönemi } & Benzin & 30731.2590 & 30.7313 & 44.3 & 1361.3948 & 3.2 & 4356.5 & 0.0044 & 265 & 1.1545 \\
\hline & Motorin & 460518.7160 & 460.5187 & 43 & $\begin{array}{c}19802.304 \\
8\end{array}$ & 3.9 & 77229.0 & 0.0772 & 265 & 20.4657 \\
\hline & LPG & 54199.1290 & 54.1991 & 47.3 & 2563.6188 & 0.2 & 512.7 & 0.0005 & 265 & 0.1359 \\
\hline
\end{tabular}

Samsun'da karayolları ulaşımından kaynaklanan $\mathrm{CO}_{2}$, $\mathrm{CH}_{4}$ ve $\mathrm{N}_{2} \mathrm{O}$ emisyonları için hesaplanan karbon ayak izi miktarları arasındaki ilişki istatistiksel olarak incelenmiştir. Buna göre, salgın öncesi ve salgın döneminde benzin $(\mathrm{p}=0.84)$ ve motorin $(\mathrm{p}=0.98)$ kullanımı istatistiksel olarak anlamlı bulunmamıştır. Salgın öncesi döneminde karayolunda benzin ve motorin tüketiminden kaynaklanan karbon ayak izi miktarı sirasıla $96.67 \mathrm{Gg}$ ve $1476.55 \mathrm{Gg}$ iken, salgın döneminde $96.76 \mathrm{Gg}$ ve $1489.98 \mathrm{Gg}$ olarak hesaplanmıştır. Çalışmada değerlendirmeye alınan salgın öncesi döneminde LPG kullanımından kaynaklanan karbon ayak izi 189.01 Gg iken salgın döneminde 166.35 Gg'dir. LPG kullanımından kaynaklanan karbon ayak izinde salgın öncesi ve salgın dönemi arasında istatistiksel olarak anlamlı bir fark bulunmuştur $(\mathrm{p}=0.001) . \mathrm{Bu}$ durum LPG kullanımından kaynaklanan sera gazı emisyonunun salgın döneminde anlamlı derecede azalarak karbon ayak izi oluşumunu azalttığını ifade etmek mümkündür.

Tier-1 yaklaşımına göre; COVID-19 salgınında Samsun'da sinırlı aktiviteler sonucu doğalgaz tüketiminden ve araçlardan kaynaklanan eşdeğer $\mathrm{CO}_{2}$ emisyon miktarlarının yakıt türüne göre dağılımı Şekil 3'te gösterilmektedir. Salgın öncesinde doğalgaz kullanımı kaynaklı $471.60 \mathrm{Gg}$ eşdeğer $\mathrm{CO}_{2}$ emisyonu atmosfere verilirken, salgın döneminde emisyon miktarı 463.44 Gg'a düşmüştür. Karayolları ulaşımında kullanılan benzin, motorin ve LPG yakıtları içerisinde eşdeğer $\mathrm{CO}_{2}$ emisyonunda en fazla düşüş \%12 azalma ile LPG'de görülmüştür.

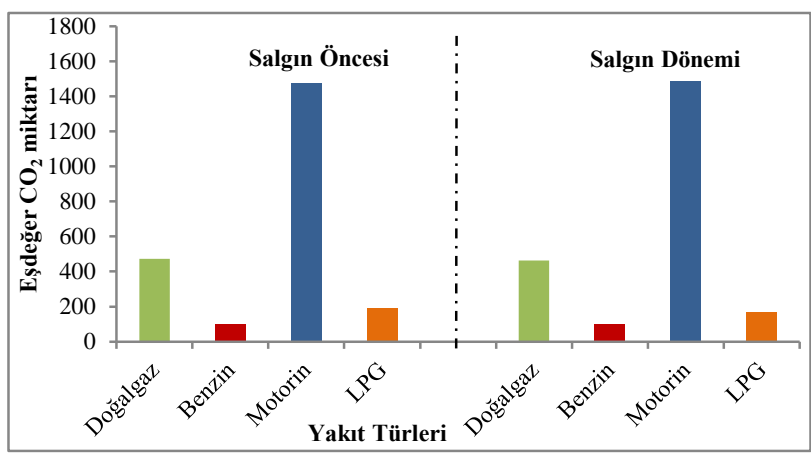

Şekil 3. Samsun'da yakıt türüne göre atmosfere salınan eşdeğer $\mathrm{CO}_{2}$ miktarları

Motorin ve benzinde ise dikkate değer bir değişiklik gözlenmemiş ve önceki yıla yakın eşdeğer $\mathrm{CO}_{2}$ emisyon salınımı oluşmuştur. Salgın öncesi seçilen dönem aralığında toplam yakıt miktarının eşdeğer $\mathrm{CO}_{2}$ emisyonuna katkısı $2233.83 \mathrm{Gg}$ iken, salgın döneminde azalma göstererek $2216.53 \mathrm{Gg}$ hesaplanmıştır. Aradaki fark, COVID-19 salgınında kısa dönem karantinanın ısınma ve ulaşım üzerindeki etkisini gösterdiği düşünülmektedir. 


\section{Sonuçlar}

Samsun'da; COVID-19 salgını nedeniyle kısıtlanmış faaliyetlerinin sera gazı emisyonuna etkisini değerlendirmek üzere, salgın öncesi ve salgın dönemi olarak seçilen dönem aralığında elde edilen veriler karșılaștırılarak, karbon ayak izi miktarı hesaplanmıştır. Isınma amaçlı doğalgaz kullanımı ve karayolu ulaşımı kaynaklı emisyon miktarlarının hesaplanması için gerekli veri setleri ilgili kurumlardan temin edilmiş ve hesaplama aşaması IPCC Tier-1 yaklaşımına göre yapılarak sera gazı emisyon miktarları belirlenmiştir. Çalışma kapsamında değerlendirmeye alınan dönemlerde, sera gazı emisyon ve eşdeğer $\mathrm{CO}_{2}$ miktarlarına bağlı olarak aşağıdaki sonuçlar elde edilmiştir: Çalışmada, doğalgaz kullanımından ve ulaşımdan kaynaklanan yakıt tüketimlerinde en düşük emisyon miktarları salgın döneminde gerçekleşmiştir. Doğalgaz kullanımı sonucu üretilen sera gazı emisyon miktarı geçen yılın aynı dönemine göre \%1.73 azalma göstermiștir ve karbon ayak izi yükünde ise 8155 ton azalmaya katkıda bulunmuştur. Karayolları ulaşımında ise salgın döneminde oluşan sera gazı emisyon miktarı salgın öncesi döneme göre \% 0.51 ile azalma trendi sergilemiştir, bu azalmanın eşdeğer $\mathrm{CO}_{2}$ miktarına etkisi ise 9141 ton olarak hesaplanmıştır. Yapılan incelemeler sonucunda, Samsun'da yakıtlar arasında en yüksek sera gazı emisyonunun karayolları ulaşımındaki yakıt tüketiminden kaynaklandığı belirlenmiștir. Çalışma kapsamında değerlendirmeye alınan salgın döneminde hem doğalgaz hem de karayollarından oluşan toplam sera gazı emisyon miktarı salgın öncesi döneme göre 16.8747 Gg azalarak, atmosfere salınan $17.3 \mathrm{Gg}$ sera gazı emisyonu elimine edilmiştir. Sonuçlardan da anlaşılacağı gibi, alınan önlemler, Samsun'da hava kalitesi üzerinde fark edilebilir sonuçları olan kirlilik emisyonlarında azalma sağlamıștır. Genel olarak, COVID-19 kısıtlamaları sırasında ulaşım sektörü ve doğalgaz kullanımı gibi bazı insan faaliyetlerinin azalması sonucu küresel hava kalitesinde iyileșme görülmüstür. Bu bilgiler 1şı̆̆ında, özellikle akaryakıtla çalışan araçlara yönelik kısıtlamalara odaklanılmalı, hava kirliliğini etkin bir şekilde kontrol etmek için yakıtla çalışan araçların kullanımı azaltılmalı ve geleneksel yakıtla çalışan araçların yerine yeni enerji kullanan araçlar teşvik edilmelidir. Toplu taşıma araçlarını seyahat etmeye teşvik ederken, araçların toplu taşıma için kullandıkları yakıt türünün iyileştirilmesine de dikkat edilmelidir. $\mathrm{Bu}$ çalışma, gelecekte çevre ile ilgili altyapı ve politikaların planlanabilmesi için, politikacılar ve araştırmacılar için kirleticilerin azaltılması üzerindeki çeşitli faktörlerin etkisini analiz etmeleri ve bunlara erişmeleri için faydalıdır. Çünkü kısıtlamanın kaldırılması ve faaliyetlerin normalleștirilmesi sonucu hava kirliliği seviyelerinde artış görülmesi kaçınılmazdır. Son olarak, salgın önlemleri kısa vadede uygulanmış olsa bile, sera gazı konsantrasyon seviyesini uzun bir süre boyunca nasıl en aza indirilebileceğini anlamak için iyi bir firsat sunmaktadır.

\section{Teșekkür}

Bu çalışmaya sağladıkları katkılarından dolayı Samsun Doğal Gaz Dağıtım A.Ş. (SAMGAZ) ve Enerji Piyasası Düzenleme Kurumu (EPDK)'na teşekkür ederim.

\section{Çıkar çatışması}

Yazar çıkar çatışması olmadığını beyan etmektedir.

Benzerlik oranı (iThenticate): $\% 9$

\section{Kaynaklar}

[1] WHO, General's opening remarks at the media briefing on COVID-19 11 March 2020. https://www.who.int/ directorgeneral/speeches/detail/who-director-generals-opening-remarks-at-the media briefing-on-covid-19--11-march-2020, Accessed 26 May 2020.

[2] V. J. Munster, M. Koopmans, N. van Doremalen, D. van Riel and E. de Wit, A novel coronavirus emerging in China-key questions for impact assessment. New England Journal of Medicine, 82(8), 692-694, 2020. https://doi.org/10.1056/NEJMp2000929.

[3] Worldometers, COVID-19 Pandemic. https://www. worldometers.info/coronavirus/, Accessed 9 September 2021.

[4] M.F. Bashir, B. Jiang, B. Komal, M.A. Bashir, T.H. Farooq, N. Iqbaland M. Bashir, Correlation between environmental pollution indicators and COVID-19 pandemic: A brief study in Californian context. Environmental Research, 187, 109652, 2020. https://doi.org/10.1016/j.envres.2020.109652.

[5] M. Pasic, I. Bijelonja and M. Pasic, Air quality during SARS-CoV-2 (COVID-19) lockdown in Sarajevo. Periodicals of Engineering and Natural Sciences, 8 (2), 884-892, 2020. http://dx.doi.org/10.21533/pen.v8i2. 1327.

[6] P. Wang, K. Chen, S. Zhu, P. Wang, and H. Zhang, Severe air pollution events not avoided by reduced anthropogenic activities during COVID-19 outbreak. Resources, Conservation and Recycling, 158, 104814,2020. https://doi.org/10.1016/j.resconrec. 2020 104814

[7] M. Krartiand M. Aldubyan, Review analysis of COVID-19 impact on electricity demand for residential buildings. Renewable and Sustainable Energy Reviews, 110888, 2021. https://doi.org/ 10.1016/j.rser. 2021.110888.

[8] C. Philippe, F.M. Bréon, S.N. Dellaert, Y. Wang, K. Tanaka, L. Gurriaran and Z. Liu, Impact of lockdowns and winter temperatures on natural gas consumption in Europe. Earth and Space Science Open Archive ESSOAr, 2021.

[9] D. Cvetković, A. Nešovićand I. Terzić, Impact of people's behavior on the energy sustainability of the residential sector in emergency situations caused by COVID-19. Energy and Buildings, 230, 110532, 2021. https://doi.org/ 10.1016/j.enbuild.2020.110532.

[10] H. Cüce ve O. Uğur, Nevșehir ilinde karayolu ulaşımından kaynaklanan sera gazı emisyonlarının Covid-19 salgını başlangıç döneminde değerlendirilmesi. Karadeniz Fen Bilimleri Dergisi, 11(1), 118-134, 2021. https://doi.org/10.31466/ kfbd.885206.

[11] X. Cao, Y. Tian, Y. Shen, T. Wu, R. Li, X, Liuand A. Lian, Emission variations of primary air pollutants 
from highway vehicles and implications during the Covid-19 pandemic in Beijing, China. International Journal of Environmental Research and Public Health, 18(8), 4019, 2021. https://doi.org/10.3390/ijerph 18084019 .

[12] Y. Camargo-Caicedo, L.C. Mantilla-Romoand T.R. Bolaño-Ortiz, Emissions reduction of greenhouse gases, ozone precursors, aerosols and acidifying gases from road transportation duringthe COVID-19 lockdown in Colombia. Applied Sciences, 11(4), 1458, 2021. https://doi.org/10.3390/app11041458.

[13] T. Wiedmannand J. Minx, A definition of 'Carbon Footprint'. Ecological economics research trends, Nova Science Publishers, 2008.

[14] IPCC, Intergovernmental Panel on Climate Change, Guidelines for National Greenhouse Gas Inventories, Volume 2, Chapter 3, Mobil Combustion. https://www.ipcc-nggip.iges.or.jp/public/2006gl/index .html, Accessed 12 August 2021.

[15] Enerji Piyasası Düzenleme Kurumu (2019a), Petrol piyasası 2019 y1lı sektör raporu. https://www.epdk. gov.tr/Detay/Icerik/3-0-107/yillik-sektor-raporu, Accessed 2 August 2021.

[16] Enerji Piyasası Düzenleme Kurumu (2020a), Petrol piyasası 2020 y1lı sektör raporu. https://www. epdk.gov.tr/Detay/Icerik/3-0-107/yillik-sektor-raporu, Accessed 2 August 2021.
[17] Enerji Piyasası Düzenleme Kurumu (2021a), Petrol piyasası 2021 yılı Ocak ve Şubat ayı sektör raporu. https://www.epdk.gov.tr/Detay/Icerik/3-0-104-1008/ petrolaylik-sektor-raporu, Accessed 2 August 2021.

[18] Enerji Piyasası Düzenleme Kurumu (2019b), Sıvılaştırılmış petrol gazları (LPG) piyasası 2019 yılı sektör raporu. https://www.epdk.gov.tr/Detay/Icerik/30-108-1002/lpgyillik-sektor-raporlari, Accessed 2 August 2021

[19] Enerji Piyasası Düzenleme Kurumu (2020b), Sıvılaştırılmış petrol gazları (LPG) piyasası 2020 yılı sektör raporu. https://www.epdk.gov.tr/Detay/Icerik/30-108-1002/lpgyillik-sektor-raporlari, Accessed 2 August 2021.

[20] Enerji Piyasası Düzenleme Kurumu. (2021b). Sıvılaştırılmış petrol gazları (LPG) piyasası 2021 yılı Ocak ve Şubat ayı sektör raporları. https://www.epdk.gov.tr/Detay/Icerik/3-0-105-1002/ lpgaylik-sektor-raporlari, Accessed 2 August 2021.

[21] IPCC Fifth Assessment Report: Climate Change 2013. https://www.ipcc.ch/report/ar5/wg1/, Accessed 7 August 2021.

[22] IPCC guidelines for national greenhouse gas inventories: reference manual,1996, https://www.ipccnggip.iges.or.jp/public/gl/invs1.html, Accessed 7 August 2021. 